\title{
Optimizing the Social Media Promotion through Instagram: A Qualitative Research Study at MSME Charisma Gold \& Jewellery
}

\author{
Hari Murti Wirawan ${ }^{1}$, Sisdjiatmo K. Widhaningrat ${ }^{2}$ \\ \{hari.mwirawan@gmail.com¹, sisdjiatmo@gmail.com²\} \\ Faculty of Economics and Business, Universitas Indonesia, Indonesia ${ }^{12}$
}

\begin{abstract}
Jewelry business is one of the craft business categories which is related to precious metal industry. Jewelry industry continues to develop and provide broad business opportunities. There are various types of jewelry products, such as rings for special events such as weddings, jewelry with custom designs, or precious metals that are used as an investment instrument. This study focuses on MSME Charisma Gold \& Jewellery. This study aims to optimize Instagram as a digital marketing channel, and it can increase the digital market. The study is conducted using qualitative method, which data are obtained by observation, in-depth interviews, surveys, and focus group discussions. Based on the data and analysis, there has been lack of promotion activities and limited used of Instagram owned by Charisma Gold \& Jewellery. The result of this research is a set of correction steps taken to increase promotional activities through Instagram for business purpose which lead to increase exposure for MSME Charisma Gold \& Jewellery. The following are steps taken in optimizing social media promotion through Instagram: switch to business account, profile configurations, choosing the caption and hashtag, product photo taking, develop the guideline of Instagram post, and creating calendar of posting schedule. Results obtained after the suggested improvements among others an increase of user interactions, increase of user discoveries on uploaded content, and increment of account followers.
\end{abstract}

Keywords: jewelry business, business coaching, micro, small, and medium enterprise, precious metal, social media, Instagram

\section{Introduction}

One of the business sectors in Indonesia that is mostly done by MSMEs is the craft industry [1]. Charisma Gold \& Jewellery was founded in 2008 is one of the MSMEs which sells jewelry products. The business issue faced by Charisma Gold \& Jewellery is lack of promotion activities. Currently, they do not have strategy and promotion activity to attract the customers.

In recent years benefits from the use of websites and social media sites include an increase in awareness and inquiries, enhanced relationship with customers, an increase in the number of new customers, enhance ability to reach customers on a global scale, and co-promotion of local businesses that enhance the image of small business in the region [2]. Social media is currently a component of most business environments. Therefore, it is very important for small businesses to understand how to use social media networks like Facebook, Instagram, 
twitter, etc. Small businesses unfortunately do not have a strategy in place when they are using social media to expand their business and engage their customers. Strategies were revealed that suggested what small businesses should do in order to engage with their customers [3].

The purpose of this research is to identify, analyze, and develop promotion strategy through Instagram. Therefore, this research as the form of business coaching is conducted to create a set of correction steps that help Charisma Gold \& Jewellery to achieve the desired goals.

\section{Literature Review}

\subsection{Social Media Marketing}

Social media promotion considered as the cost-effective way to generating exposure, upselling, building partnership, and improving customer engagement [4].

Social media can help companies to build their digital presence, by:

a) Increase brand awareness where social media can provide a very broad reach to increase the efficiency of disseminating content and messages compared to traditional marketing channels;

b) build a reputation, where social media can help brands in telling their background;

c) social media channels can drive visitors to the company's website;

d) improve relations with the audience [5].

\subsection{Instagram Marketing}

Instagram, one of the social media platforms with significant growth in the overall user base, can be used as a media product promotion and connecting the company with its customers because it can reach millions of people at once without incurring any costs in using it. Visual content used allows companies to post pictures and videos about products, events, and other information related to a particular company or brand to increase exposure in creative ways [6].

\subsection{Previous Research}

Previous research on "Impact of social media on small business" by Nory Jones, Richard Borgman, and Ebru Ulusoy discusses the role of internet, specifically website and social media for small business. The result of the study are benefits of using website and social media which have impact with purchase decision, maintain customer relationship, and decide how to advertise to the desired market. Thus, website and social media are potential tools to help small business to increase the sales and maintain of website and social media need resource accordingly with business owner have to spare the resource [2].

Previous research on "Social Media for Marketing by Small business" by Kira Gholston and Matthew Kuofie discuss the importance of social media in business environment. The result of the study is sales increase while set the priorities to build relationship with customer, where interaction between business and customer will formed while there is promotional contact posted [3].

Previous research on "A study of factors influencing customers' purchasing behaviors of gold ornaments" by Navarwan Chaisuriyathavikun and Prattana Punnakitikashem. The result 
of the study are two major factors that are significantly related with customers' intention to purchase gold ornaments; these factors are buyer preference and expected future value. These results can help gold retailers to develop appropriate marketing strategies and enhance business success in changing environments [7].

Previous research on "Utilization of Social Media as an Effort to Increase Exposure and Media Promotion at MSME Trijaya Ban 83" by Fadhlan Hamini discusses the implementation of social media in conducting marketing activities in the digital world. The results of this study are improvements in social media provide a significant increase to company exposure, and social media can be used as a digital promotion media that is very effective [8].

Previous research on "Successful Social Media Marketing on Instagram" by M. Nummila. The result of this study states that for any company, Instagram can be very useful when used correctly. When successfully adapting Instagram as part of a social media strategy and learning how to use it most efficiently, companies can gain a competitive advantage over other brands. Marketing on Instagram can also increase company sales and increase brand awareness quickly [9].

\section{Method}

\subsection{Research Approach}

The business coaching research uses qualitative methods by gathering information from multiple sources concerned with the research.

\subsection{Object/Subject of The Research}

The object of this research is Instagram social media promotion which is used to increase MSME Charisma Gold \& Jewellery exposure. While the subject of this study is MSME Charisma Gold \& Jewellery, which the offline store located at Melawai Plaza, 1st floor, South Jakarta, Indonesia. This store provides gold, diamond, and palladium-based jewelry. Charisma also accepts custom design from its customers, which takes from 1 to 7 days before deliver to customers. Charisma also sells and buys precious metal. Charisma also provides services like jewelry repair and jewelry buyback from their customer whether those jewels previously bought from Charisma or other stores.

\subsection{Research Data Collection \& Sources}

The data used in the study consisted of two types, primary data and secondary data. Primary data is source of data that directly provides data to data collectors [10]. The acquisition of primary data in this study is by conducting direct observations to the offline store with unstructured observation technique. The researcher also performs discussion and interview with the owner and employee of the MSME with unstructured interview technique. The researcher also conduct survey to 83 respondents which is Charisma's Customer Segments with convenience sampling technique between January to March 2020. Focus Group Discussion (FGD) also performed which is conducted between January 2020 and March 2020 to get inside from Charisma's Customer Segments regarding jewelry to 15 respondents with open-ended questions [11]. The survey and FGD was conducted to determine consumer behavior and factors that influence respondents when buying jewelry. 
While secondary data is a source of data which has been collected for other purpose [10]. In this research secondary data was obtained from the sales data from Charisma Gold \& Jewellery and also from literature studies from previous research journals, articles, and books. In this study conducted a qualitative research approach in the business coaching process. In the accordance with business coaching conducted at Charisma Gold \& Jewellery, the author explores information from Charisma's in detail and help Charisma to resolve the problems faced and objectives of the business coaching can be carried out.

\subsection{Data Analysis Method}

In analyzing data, there steps that will be followed:

a) Data selection

b) Data presentation

c) Conclusion and verification [10]

Those three steps are carried out using content analysis and triangulation. In this study, author triangulated information and data obtained from the results of interview, observation, focus group discussion, and survey, to obtain comprehensive picture and confirmation regarding the conditions of Charisma Gold \& Jewellery.

\section{Result And Discussion}

Based on the interview and observation, it was found that Charisma Gold \& Jewellery since its establishment until now has not had identification of product promotions, does not have strategies and activities undertaken to attract customers. Based on survey, respondents search for jewelry information through social media, testimony from other customers can affect respondents' preferences, respondents choose jewelry because of the designs they like, and trust in sellers and discounts are factors considered by respondents. Then based on FGD, testimony is factor considered by respondents, offline stores are still a priority for high involvement products, respondents prefer to use Instagram to find information about jewelry, and promotional programs can attract interest in buying decision.

Several tools were used to analyze the data obtained. Market opportunity analysis (segmenting, targeting, positioning) is used for determining the consumers to be addressed. Then Internal analysis through marketing mix to create marketing strategy in order to achieve the company's goals within the predetermined target market [12]. External analysis uses Porter's Five Forces to analyze competition in the industry in order to fully understand and assess the company's current situation [13].

SWOT analysis is then used to measure the company's internal strengths, internal weaknesses, opportunities in the market, and threats that affect the company's sustainability [13]. After conducting SWOT analysis, then proceed with the TOWS matrix. There are four strategies that can be developed, namely SO (strength-opportunities) strategy, ST (strengththreats) strategy, WO (weakness-opportunities) strategy, and WT (weakness-opportunities) strategy [14].

From the results of the conducted analysis, the problems summarized in the gap analysis will be given a weighting based on the urgency and ability of MSME to resolve the problem, which is called pareto analysis. Gap analysis is a comparison between ideal conditions (the conditions that MSME owners want to achieve) with the real conditions that are currently 
being experienced. Gap analysis can also identify actions that need to be taken to reduce gaps and achieve expected performance. The results of the Pareto analysis can be seen in Table 1.

Table 1. Pareto Urgency Table

\begin{tabular}{|c|c|c|c|c|c|c|}
\hline No & Problems & Value & Ability & Contribution & Distribution & Accumulation \\
\hline 1 & $\begin{array}{l}\text { Social media } \\
\text { promotion }\end{array}$ & 4 & 10 & 40 & $46 \%$ & $46 \%$ \\
\hline 2 & Signage & 3 & 9 & 27 & $31 \%$ & $77 \%$ \\
\hline 3 & Product & 3 & 5 & 15 & $17 \%$ & $94 \%$ \\
\hline 4 & $\begin{array}{l}\text { Job } \\
\text { description }\end{array}$ & 1 & 5 & 5 & $6 \%$ & $100 \%$ \\
\hline Total & & & & 87 & $100 \%$ & $100 \%$ \\
\hline
\end{tabular}

The Instagram platform was chosen for several reasons, one of which is the ease of access for Charisma owners at anytime and anywhere to be able to review and communicate with followers, either by uploading new photos or replying to messages and comments from followers. Charisma owner also has an Instagram account and has no difficulty in accessing it.

The additional features of an Instagram business account can provide insight into demographic data and follower activity as well as the extent of the uploaded content. Thus, can facilitate Charisma Gold \& Jewellery in evaluating and comparing which content is the most interesting and liked, as well as being one of the measuring tools in seeing the performance of each uploaded image post.

Information delivery will be more effective when using visual and image communication because humans can more quickly capture messages in visual form when compared to text [15]. Therefore, Instagram is a popular platform because not only has a very large number of users, but Instagram also emphasizes the tendency of using visual content in conducting social media marketing $[16,17]$.

The following are steps taken in developing strategies for optimizing social media promotion through Instagram: (1) Switch to business account, with this account Charisma gets insight features to analyze the followers. Insight displays demographics, activity, content, and audience. (2) Profile configurations, by completing bio information including logo, adding highlights, and grouping them orderly. (3) Caption and hashtag development, choosing the caption used for each photo upload is minor but crucial for the company's marketing strategy [18]. The hashtag will make the content grouped with other contents with the same hashtag. The hashtag forms a clickable link to the collection of content with the hashtag. (4) Product photo taking. (5) Develop the guideline Instagram post, which are used to standardize uploading photos on Instagram. (6) Creating calendar posting schedule, which includes content to be promoted, creator, frequency of posts, target audience, and ways to promote content [19].

The result after the social media promotion was that the number of user interactions with Charisma Gold \& Jewellery increased to 43 in one week, where 32 users visit the Charisma Gold \& Jewellery profile, 6 users clicked on the website and 5 users get the direction of the location. Improvements were also seen in the discovery section, which is the total number of users who saw uploaded content (Reach) to 20 times. Besides, the impression gained by Charisma Gold \& Jewellery also increased to 414 in the period 12 to 18 June 2020. Follower from Charisma Gold \& Jewellery also increased from 293 accounts to 330 follower accounts. 


\section{Conclusions}

The conclusion from the series of Business Coaching activities is Charisma's Instagram social media has been optimized to support Charisma's business marketing activities. Achievement results in optimizing promotion activities through Instagram are an increase in exposure and the amount of user interaction with Charisma Gold \& Jewellery that can be measured by looking at Instagram insight as well as an increase in the number of followers who follow Charisma Gold \& Jewellery Instagram account.

Based on external and internal analysis, there are other business issue which faced by Charisma Gold \& Jewellery such as physical signage, product, and job description. However, this study only focusses on social media promotion. Improvement in other area is required to leverage Charisma Gold \& Jewellery in the business competition.

\section{References}

[1] Indonesia Creative Economy Agency.: Statistic Data. Retrieved from www.bekraf.go.id (2018)

[2] Jones, N., Borgman, R., \& Ulusoy, E.: Impact of Social Media on Small Business. Journal of Small Business and Enterprise Development, 22(4), 611-632. https://doi.org/10.1108/JSBED09-2013-0133 (2015)

[3] Gholston, K., Kuofie, M., \& Hakim, A. C.: Social Media for Marketing by Small Business. Journal of Marketing and Management, 7 (May), 24-39 (2016)

[4] Si, Sajid.: Social Media and Its Role in Marketing. Business and Economics Journal, 7(203). https://www.hilarispublisher.com/open-access/social-media-and-its-role-in-marketing-21516219-1000203.pdf (2016)

[5] Kaufan, I., \& Horton, C.: Digital Marketing: Integrating Strategy and Tactics with Values. Routledge, New York. Retrieved from http://dmresourcecenter.com/wpcontent/themes/DMRC/documents/DMB-Instructors-Roadmap.pdf (2015)

[6] Belch, G. \& Belch, M.: Advertising and Promotion: An Integrated Marketing Communications Perspective. McGraw-Hill Education, New York (2018)

[7] Chaisuriyathavikun, N., \& Punnakitikashem, P.: A study of factors influencing customers' Purchasing behaviours of gold ornaments. Journal of business and retail management research. (10)3, 147-159 (2016)

[8] Hamini, Fadhlan.: Utilization of Social Media as an Effort to Increase Exposure and Media Promotion at MSME Trijaya Ban 83 Workshop. Master Thesis on Magister Management, Faculty of Economics and Business, Universitas Indonesia (2017)

[9] Nummila, M.: Successful Social Media Marketing on Instagram. Bachelor's Thesis Degree Programme in International Business, Haaga-Helia University of Applied Sciences (2015)

[10] Malhotra, N.K.: Marketing Research: An Applied Orientation (6 $6^{\text {th }}$ edition). Pearson Education, New Jersey (2010)

[11] Krueger, R.A.: Focus Group: A Practical Guide for Applied Research. Sage Publications, Thousand Oaks (1988)

[12] Mullins, John W. \& Orville C. Walker, Jr.: Marketing Management: A strategic decision marketing approach 8th ed. McGraw-Hill, New York (2013)

[13] Thompson, Peteraf, Gamble, Strickland.: Crafting and Executing Strategy: The Quest for Competitive Advantage, Concepts and Cases 21th Edition. McGrew-Hill Education, New York (2018)

[14] Chaffey, Dave \& Chadwick, Fiona Ellis.: Digital Marketing Strategy, Implementation, and Practice 6th Edition. Pearson Education Limited, Harlow (2016) 
[15] Meggs, P.B., \& Purvis, A.W.: Meggs' History of Graphic Design. New Jersey: John Wiley \& Sons, Inc (2006)

[16] Neher, K.: Social Media Marketing. Harnessing Images, Instagram, Infographics and Pinterest to Grow your Business Online. Boot Camp Publishing, Cincinnati, OH (2013)

[17] Stelzner, M.A.: Social Media Marketing Industry Report. Retrieved on 14 Mei 2020 from www.socialmediaexaminer.com/report2016 (2016)

[18] Macarthy, Andrew.: 500 Social Media Marketing Tips. CreateSpace (2015)

[19] Hollensen, Kotler, \& Opresnik.: Social Media Marketing: A Practitioner Guide, 2nd Ed. Opresnik Management Guides (2017) 